\title{
Comparison of the radius bone density between the right and left arms of female college badminton and soft-tennis players
}

\author{
Hiroyuki NISHIDA', Yasufumi TAKEMOTO², Kaei WASHINO ${ }^{3}$ \\ Nobuharu KUWABARA ${ }^{4}$, Tsuyoshi YOKOYAMA ${ }^{5}$ \\ Haruo SUGIURA ${ }^{1}$ and Masaru NAKAGAMI ${ }^{6}$
}

This study was carried out to clarify the ideal motion for maintaining and improving bone density. Radius bone density between the right and left arms of badminton and soft-tennis players, whose main operation was asymmetric, was compared. Summaries of the findings are as follows.

1) In badminton and soft-tennis players who showed dominant handedness, there was a contralateral difference in bone density. The contralateral difference rate was $3.3 \%$ in soft-tennis players, and $8.1 \%$ in the badminton players.

2) These contralateral difference were due to differences in the racket weight and the degree of shock and batting method, and these differences produced the load for the radius.

3) The contralateral differences in radius bone density in soft-tennis players was related to the contralateral differences of grip strength, duration of sports experience and technical abilities.

4) There was a close relationship between the radius bone density, the forearm girth and grip strength, and it appeared that muscle quantity of the forearm was one of the factors which regulated the radius bone density.

From the above findings, the continuation of sports using dominant arm resulted in an imbalance of the radius bone density between the non-dominant side and the dominant arm. Sports players whose main motions are asymmetric should adopt training which loads the non-

\footnotetext{
'岐皁薬科大学

${ }^{2}$ 岐皋聖德学園大学

${ }^{3}$ 岐皁大学医学部

${ }^{4}$ 東海女子短期大学

${ }^{5}$ 加茂医師会立総合保健センター

6京都ノートルダム女子大学

${ }^{\prime}$ Gifu Pharmaceutical University

${ }^{2}$ Gifu Shotoku Gakuen University

${ }^{8}$ Gifu University School of Medicine

${ }^{4}$ Tokai Women's Junior College

${ }^{5}$ Laboratory of Kamo General Health

${ }^{6}$ Notre Dame women's College of Kyoto
} 
dominant arm side to maintain a well-balanced radius bone density.

Key words : female athlete, bone mineral density of radius, side-to-side difference, badminton, softtennis

\section{Introduction}

In the progress to an aged society, osteoporosis has become one of the most influential diseases and therefore the establishment of prophylaxis is urgent.

In this respect, exercise appears to promote osteogenesis in the course of stimulation by landing impact and muscle contraction around the bone. The bone density of an athlete with regular sport participant is high (Stillman et al., 1986; Grimston et al., 1993). This indicates that continual motion can aid prevention and act as a therapy against osteoporosis. However, the negative viewpoint is also frequently reported regarding the increase in the bone density in all parts of the body skeleton by exercise (Colletti et al., 1989; Simkin et al., 1987).

Recently, various studies have been made to clarify these problems. For example, the differences in dynamic stress to bone have been examined among sports (Heinonen et al., 1995; Alfredson et al., 1997) and among individual bones (Haapasalo et al., 1994; Alfredson et al., 1996). However, the majority of research has examined only the effect on the spine and femura, etc. Although there are regular sports participants who mainly use hands and arms, especially in racket sports, the effect on the radius bone remains to be elucidated.

In the present study, the radius bone density of both arms was examined in female athletes who showed dominant handedness. Therefore, the bone density of two popular sports, badminton and soft-tennis, were ex- amined.

\section{Methods}

\section{Subjects}

Subjects were badminton and soft-tennis players in the T-women's college in Gifu Prefecture ( $\mathrm{n}=18$ and 22 , respectively). The control subjects were softball players using both hands in sports activity $(\mathrm{n}=25)$ and general students without sports experience previously belonging to a club activity $(n=16)$. Overall, there were 40 cases and 41 controls. The mean age with SD for subjects was $19.7 \pm 1.0$. The athletes were recruited from teams which always had good results in the national college competitions. The subjects were players with over 5 years experience of their sports, in order to unify the technology level and years of sports experience as much as possible. Before entry to this study the possibility of slight radiation exposure was explained and informed consent was obtained.

\section{Data collection}

The measurements were carried out after the sport season had ended in November, 1998. The measurement of bone mineral density (BMD: $\mathrm{g} / \mathrm{cm}^{2}$ ) was performed on the DCS-600 (ALOKA Inc., Tokyo) by the DEXA (Dual Energy X-ray Absorptiometry) method. BMD was measured at the forearm radius ( $1 / 3$ position from the end) by the Profile Scan (R3: single scan). BMD as an index of bone quality was calculated as bone mineral content $(\mathrm{g} / \mathrm{cm})$ divided by bone width (cm). One tester measured all participants to 
limit the variability in measuring, and the measurement of BMD was conducted once only for each arm to minimize the X-ray irradiation.

\section{Anthropometric measures}

The anthropometric measures were carried out on the same day as the measurement of BMD. The items of anthropometric measure were body height, body weight, length of both forearms and the maximum and minimum value of the forearm girth (Natori et al., 1975). The grip strength was measured as a function item. The sports activities, starting age and the duration for each sport were collected by asking subjects. The supervisor of each sport team evaluated the sport technology rank of each player in three ranks (3 points: Central player, 2 points: Semi-central player, 1 point: Duplicate player) to observe the relation with the sport technology.

\section{Statistical analysis}

1) The following factors were compared among the sports. (1) body height, body weight, sports starting age and duration of sports history. (2) BMD, anthropometric measurement items in the forearm (length of the forearm, maximum and minimum value of the forearm girth) and grip strength. (3) Sideto-side difference rates* for BMD, measurement items of forearm and grip strength. One-way ANOVA and Scheffe's method (for multiple comparison) were used for analysis.

*Side-to-side difference rates: ((dominant value)-(non-dominant value))/(non-dominant) $\times 100$

2) The difference in BMD between each arm
The badminton and soft-tennis players were divided into 3 groups by the modification of plus/minus $1 / 2$ standard deviation (SD) with the mean value of each side-to-side BMD difference rate (large group: mean $+1 / 2 \mathrm{SD}$ or more, medium group: mean $\pm \mathrm{SD}$, small group: mean $-1 / 2 \mathrm{SD}$ or less) The following characteristics were compared between dominant and non-dominant arm using the paired t- test; BMD, side-to-side difference rates between the right and left forearm (forearm length, maximum and minimum value of the forearm girth), sports duration and technology ranks, etc. (For comparison between items and inter-group comparison, multiple comparison of Scheffe's method was carried out, after it was compared by one-way ANOVA). All statistical significance levels were set at $5 \%$.

\section{Results}

1) Comparisons among sports items

(1) Anthropometric findings, sports-related-items (Table 1)

Softball players showed higher body weight and BMI than general students. The mean starting age of the badminton player was 9.4-years-old, which was the earliest among the groups. Duration of sports experience was also the longest (10.7 years) in badminton players, and there was a significant difference between the other 2 sports.

(2) Bone density, length of the forearm, maximum and minimum value of the forearm girth and grip strength (Table 2)

The softball player showed the highest mean value of $\mathrm{BMD}$ of both arms $(0.650$ $\left.\mathrm{g} / \mathrm{cm}^{2}\right)$, and there was a significant difference compared with that of the general student $\left(0.612 \mathrm{~g} / \mathrm{cm}^{2}\right)$. Although a significant differ- 
ence could not be recognized for BMD among the 3 sports in the dominant arm, there was a significant difference between the 3 sports and the general students. In addition, the softball player showed the highest BMD value $\left(0.647 \mathrm{~g} / \mathrm{cm}^{2}\right)$ in the non-dominant arm side, and the badminton player was the second $\left(0.620 \mathrm{~g} / \mathrm{cm}^{2}\right)$. The soft-tennis player and general student showed almost equal values. However, the badminton and soft-ten- nis players showed the most significant differences in the side-to-side differences rates of BMD. There was no significant difference in the length of the forearm among the sports. There was significant difference only in the soft-tennis players for the values between right and left arms. Athletes had higher maximum and minimum values of the forearm girth than the general student, but they did not show a significant difference

Table 1 Characteristics of study subjects by sports

\begin{tabular}{|c|c|c|c|c|c|}
\hline \multirow{2}{*}{\multicolumn{2}{|c|}{$\operatorname{Item}(\mathrm{N})$}} & \multicolumn{3}{|c|}{ Athletes } & \multirow{2}{*}{$\begin{array}{c}\text { General } \\
\text { student } \\
\quad(16)\end{array}$} \\
\hline & & $\begin{array}{l}\text { Badminton } \\
(18)\end{array}$ & $\begin{array}{c}\text { Soft-tennis } \\
(22)\end{array}$ & $\begin{array}{l}\text { Softball } \\
\text { (25) }\end{array}$ & \\
\hline Age & (yr.) & $20.1 \pm 0.9$ & $19.6 \pm 1.3$ & $19.7 \pm 0.9$ & $19.6 \pm 0.9$ \\
\hline Height & $(\mathrm{cm})$ & $159.9 \pm 3.7$ & $159.1 \pm 3.3$ & $158.0 \pm 5.3$ & $157.3 \pm 4.2$ \\
\hline Body weight & $(\mathrm{kg})$ & $55.5 \pm 5.1$ & $54.5 \pm 3.2$ & $56.4 \pm 6.1 \mathrm{~g} *$ & $52.2 \pm 6.1$ \\
\hline $\mathrm{BMI}$ & (index) & $21.7 \pm 1.7$ & $21.5 \pm 1.3$ & $22.6 \pm 2.0 \mathrm{~g} *$ & $21.1 \pm 2.5$ \\
\hline Sports beginning age & (yr.) & $9.4 \pm 1.8 \mathrm{t} * \mathrm{~s} *$ & $10.8 \pm 1.5$ & $11.1 \pm 1.6$ & - \\
\hline Sports experience years & (yr.) & $10.7 \pm 2.1 \mathrm{t} * \mathrm{~s} *$ & $8.8 \pm 2.1$ & $8.6 \pm 1.8$ & - \\
\hline
\end{tabular}

$* \mathrm{p}<0.05: \mathrm{vs}(\mathrm{t}=$ soft-tennis, $\mathrm{s}=$ softball, $\mathrm{g}=$ general student $)$

Table 2 Comparison of bone density and measured variables in forearm by arm or by sports

\begin{tabular}{|c|c|c|c|c|c|c|c|c|c|}
\hline & & \multicolumn{7}{|c|}{ Athletes } & \multirow{2}{*}{$\begin{array}{c}\text { General student } \\
\text { (16) }\end{array}$} \\
\hline \multicolumn{2}{|c|}{$\operatorname{Item}(\mathrm{N})$} & \multicolumn{2}{|c|}{$\begin{array}{l}\text { Badminton } \\
(18)\end{array}$} & \multicolumn{3}{|c|}{$\begin{array}{l}\text { Soft-tennis } \\
\quad(22)\end{array}$} & \multicolumn{2}{|c|}{$\begin{array}{l}\text { Softball } \\
\quad(25)\end{array}$} & \\
\hline \multirow{3}{*}{$\begin{array}{l}\text { Bone density } \\
\left(\mathrm{g} / \mathrm{cm}^{2}\right)\end{array}$} & dominant & $0.640 \pm 0.030$ & $\mathrm{~g} * \#$ & $0.651 \pm 0.049$ & $\mathrm{~g}^{*}$ & \# & $0.654 \pm 0.044$ & $g^{*}$ & $0.612 \pm 0.055$ \\
\hline & non-dominant & $0.620 \pm 0.028$ & $t^{*}$ & $0.602 \pm 0.031$ & & & $0.647 \pm 0.050$ & & $0.606 \pm 0.052$ \\
\hline & average & $0.630 \pm 0.028$ & & $0.626 \pm 0.037$ & & & $0.650 \pm 0.046$ & $\mathrm{~g}^{*}$ & $0.609 \pm 0.053$ \\
\hline \multirow{3}{*}{$\begin{array}{l}\text { Forearm length } \\
(\mathrm{cm})\end{array}$} & dominant & $23.9 \pm 0.9$ & & $24.2 \pm 0.8$ & & \# & $23.9 \pm 1.0$ & $\cdot$ & $23.6 \pm 0.9$ \\
\hline & non-dominant & $23.7 \pm 0.9$ & & $23.3 \pm 0.8$ & & & $23.5 \pm 1.0$ & & $23.2 \pm 1.0$ \\
\hline & average & $23.8 \pm 1.1$ & & $23.7 \pm 0.7$ & & & $23.7 \pm 0.9$ & & $23.4 \pm 1.8$ \\
\hline \multirow{3}{*}{$\begin{array}{l}\text { Forearm girth } \\
\text { (maximum) } \\
(\mathrm{cm})\end{array}$} & dominant & $23.3 \pm 1.1$ & $\mathrm{~g}^{*} \#$ & $23.5 \pm 1.0$ & $\mathrm{~g}^{*}$ & \# & $23.9 \pm 1.4$ & $\mathrm{~g}^{*}$ & $22.2 \pm 1.8$ \\
\hline & non-dominant & $21.6 \pm 1.1$ & & $21.3 \pm 1.0$ & & & $23.5 \pm 1.5$ & $\mathrm{~b} * \mathrm{t} * \mathrm{~g} *$ & $21.8 \pm 1.7$ \\
\hline & average & $22.5 \pm 1.1$ & & $22.4 \pm 0.9$ & & & $23.7 \pm 1.4$ & $b^{*} t^{*} g^{*}$ & $22.0 \pm 1.7$ \\
\hline \multirow{3}{*}{$\begin{array}{l}\text { Forearm girth } \\
\text { (minimum) } \\
(\mathrm{cm})\end{array}$} & dominant & $15.7 \pm 1.0$ & $\mathrm{~g} * \#$ & $15.6 \pm 0.6$ & $\mathrm{~g}^{*}$ & \# & $15.9 \pm 1.0$ & $\mathrm{~g}^{*}$ & $14.9 \pm 1.3$ \\
\hline & non-dominant & $15.1 \pm 0.8$ & $\mathrm{~g}^{*}$ & $14.8 \pm 0.6$ & $g^{*}$ & & $15.9 \pm 0.9$ & $b^{*} t^{*} g^{*}$ & $14.7 \pm 1.2$ \\
\hline & average & $15.4 \pm 0.9$ & & $15.2 \pm 0.6$ & & & $15.9 \pm 0.9$ & $t * g *$ & $14.8 \pm 1.2$ \\
\hline \multirow{3}{*}{$\begin{array}{l}\text { Grip strength } \\
(\mathrm{kg})\end{array}$} & dominant & $31.4 \pm 4.5$ & $\mathrm{~g} * \#$ & $31.4 \pm 3.5$ & $\mathrm{~g}^{*}$ & \# & $30.5 \pm 4.3$ & $\mathrm{~g}^{*}$ & $23.3 \pm 4.3$ \\
\hline & non-dominant & $26.7 \pm 3.4$ & $\mathrm{~g}^{*}$ & $25.4 \pm 3.2$ & $\mathrm{~g} *$ & & $29.6 \pm 3.8$ & $\mathrm{~b} * \mathrm{t} * \mathrm{~g} *$ & $21.8 \pm 3.1$ \\
\hline & average & $29.0 \pm 3.8$ & $\mathrm{~g}^{*}$ & $28.4 \pm 3.0$ & $\mathrm{~g} *$ & & $30.3 \pm 3.9$ & $\mathrm{~g}^{*}$ & $22.6 \pm 3.6$ \\
\hline
\end{tabular}

\# $\mathrm{p}<0.05$ (dominant : non-dominant)

$*_{\mathrm{p}}<0.05$ : vs. $(\mathrm{b}=$ badminton, $\mathrm{t}=$ soft-tennis, $\mathrm{s}=$ softbal, $\mathrm{g}=$ general student) 
among sports. However, in the non-dominant arm, the softball players had a higher value than the badminton players, soft-tennis players and general students. Athletes showed higher grip strength than the general students. However, there was a contralateral difference in badminton and soft-tennis player.

(3) Side-to-side difference rate (Table 3)

The soft-tennis players showed the largest contralateral difference rates in BMD, length and forearm girth (maximum and minimum values), which were significantly larger compared with those of the other groups. Grip strength showed the highest contralateral difference rate (soft-tennis $24.8 \%$, badminton $17.8 \%$, softball $3.3 \%$, general student $6.5 \%$ ), where the badminton players had significantly higher values than the softball players and general students, except for the length of the

Table 3 Comparison of side-to-side difference rate of bone density and measured variables in forearm by sports

\begin{tabular}{|c|c|c|c|c|c|c|}
\hline \multirow{3}{*}{$\begin{array}{l}\text { Item (N) } \\
\text { Bone density }\end{array}$} & \multicolumn{5}{|c|}{ Athletes } & \multirow{3}{*}{$\begin{array}{c}\begin{array}{c}\text { General student } \\
\text { (16) }\end{array} \\
0.97 \pm 3.37\end{array}$} \\
\hline & \multicolumn{2}{|c|}{$\begin{array}{l}\text { Badminton } \\
\text { (18) }\end{array}$} & \multicolumn{2}{|c|}{$\begin{array}{l}\text { Soft-tennis } \\
\quad(22)\end{array}$} & \multirow{2}{*}{$\begin{array}{c}\begin{array}{c}\text { Softball } \\
(25)\end{array} \\
1.15 \pm 2.73\end{array}$} & \\
\hline & $3.28 \pm 2.56$ & $\mathrm{~s} * \mathrm{~g} *$ & $8.11 \pm 5.21$ & $b * s * g *$ & & \\
\hline Forearm length & $1.19 \pm 1.69$ & & $4.12 \pm 2.12$ & $b^{*} s^{*} g *$ & $1.81 \pm 1.96$ & $1.91 \pm 1.60$ \\
\hline Forearm girth (maximum) & $8.22 \pm 1.85$ & $\mathrm{~s}^{*} \mathrm{~g} *$ & $10.35 \pm 3.81$ & $b * s * g *$ & $2.03 \pm 2.26$ & $1.90 \pm 3.94$ \\
\hline Forearm girth (minimum) & $4.48 \pm 1.69$ & $\mathrm{~s}^{*} \mathrm{~g} *$ & $5.84 \pm 2.50$ & $b * s * g *$ & $0.03 \pm 2.34$ & $1.18 \pm 3.02$ \\
\hline Grip strength & $17.77 \pm 10.26$ & $\mathrm{~s}^{*} \mathrm{~g} *$ & $24.77 \pm 12.17$ & $\mathrm{~b} * \mathrm{~s} * \mathrm{~g} *$ & $3.30 \pm 7.80$ & $6.46 \pm 11.70$ \\
\hline
\end{tabular}

$*=p<0.05:$ VS $(b=$ badminton, $t=$ soft-tennis, $s=$ softball, $g=$ general student $)$

Table 4 Comparison of bone density, sports experience years, technology rank in the 3 groups divided by the side-to-side difference rate of bone density

\begin{tabular}{|c|c|c|c|c|c|c|c|}
\hline & Badminton & $(\mathrm{N})$ & & \multicolumn{2}{|l|}{ Large (6) } & Medium (6) & Small (6) \\
\hline \multirow[t]{2}{*}{ Bone density } & (dominant) & & $\left(\mathrm{g} / \mathrm{cm}^{2}\right)$ & $0.654 \pm 00.33$ & & $0.636 \pm 0.031$ & $0.636 \pm 0.031$ \\
\hline & (non-dominant) & & $\left(\mathrm{g} / \mathrm{cm}^{2}\right)$ & $0.616 \pm 0.029$ & & $0.161 \pm 0.030$ & $0.628 \pm 0.028$ \\
\hline \multicolumn{3}{|c|}{ Forearm length of side-to-side difference rate } & $(\%)$ & $2.14 \pm 1.94$ & & $0.37 \pm 0.91$ & $1.05 \pm 1.80$ \\
\hline \multicolumn{3}{|c|}{ Forearm girth (maximum) of side-to-side difference rate } & $(\%)$ & $8.82 \pm 1.15$ & & $8.44 \pm 2.64$ & $7.39 \pm 1.42$ \\
\hline \multicolumn{3}{|c|}{ Forearm girth (minimum) of side-to-side difference rate } & $(\%)$ & $4.25 \pm 1.56$ & & $5.00 \pm 2.27$ & $4.20 \pm 1.29$ \\
\hline \multicolumn{3}{|c|}{ Grip strength of side-to side difference rate } & $(\%)$ & $19.31 \pm 14.09$ & & $15.76 \pm 9.81$ & $18.24 \pm 7.42$ \\
\hline \multicolumn{3}{|c|}{ Sports experience years } & (yr.) & $10.33 \pm 1.97$ & & $11.83 \pm 1.33$ & $9.83 \pm 1.33$ \\
\hline \multicolumn{3}{|c|}{ Technology rank } & (point) & $2.50 \pm 0.55$ & & $2.50 \pm 0.55$ & $2.00 \pm 0.89$ \\
\hline & Soft-tennis & $(\mathrm{N})$ & & \multicolumn{2}{|l|}{ Large (7) } & Medium (7) & Small (8) \\
\hline \multirow[t]{2}{*}{ Bone density } & (dominant) & & $\left(\mathrm{g} / \mathrm{cm}^{2}\right)$ & $0.691 \pm 0.034$ & $m * s *$ & $0.650 \pm 0.042$ & $0.616 \pm 0.041$ \\
\hline & (non-dominant) & & $\left(\mathrm{g} / \mathrm{cm}^{2}\right)$ & $0.605 \pm 0.028$ & & $0.602 \pm 0.033$ & $0.598 \pm 0.034$ \\
\hline \multicolumn{3}{|c|}{ Forearm length of side-to-side difference rate } & $(\%)$ & $4.66 \pm 2.35$ & & $4.89 \pm 1.69$ & $2.98 \pm 1.97$ \\
\hline \multicolumn{3}{|c|}{ Forearm girth (maximum) of side-to-side difference rate } & (\%) & $10.84 \pm 3.87$ & & $10.43 \pm 4.10$ & $9.85 \pm 3.98$ \\
\hline \multicolumn{3}{|c|}{ Forearm girth (minimum) of side-to-side difference rate } & $(\%)$ & $5.79 \pm 2.37$ & & $6.90 \pm 2.47$ & $4.96 \pm 2.58$ \\
\hline \multicolumn{3}{|c|}{ Grip strength of side-to side difference rate } & $(\%)$ & $28.34 \pm 8.21$ & $\mathrm{~s}^{*}$ & $28.88 \pm 16.18$ & $18.05 \pm 9.00$ \\
\hline \multicolumn{3}{|c|}{ Sports experience years } & (yr.) & $10.00 \pm 2.38$ & $\mathrm{~s}^{*}$ & $9.14 \pm 2.12$ & $7.50 \pm 1.07$ \\
\hline \multicolumn{3}{|c|}{ Technology rank } & (point) & $2.43 \pm 0.79$ & $\mathrm{~s}^{*}$ & $2.00 \pm 1.00$ & $1.63 \pm 0.74$ \\
\hline
\end{tabular}

\footnotetext{
${ }^{*} \mathrm{p}<0.05:$ vs. $(\mathrm{m}=$ Medium, $\mathrm{s}=$ Small $)$
} 
forearm.

2) Exploration to determine the relative factor for the contralateral difference rate of BMD.

$\mathrm{BMD}$, sports duration and technology ranks, among the 3 subdivided groups were compared in soft-tennis and badminton players (Table 4).

There was no significant difference in all measured items among the 3 inter-groups in badminton players. However, the "large" group had a greater grip strength, longer sports experience and higher technology rank than the "small" group in soft-tennis players.

\section{Discussion}

The bone density in the dominant arm of athletes showed a higher value than the general student in all sport players. From this finding, it was realized that sport experience during growth was important to raise peak bone mass. On the increase in bone density, there are previous studies which have examined differences among sports (Risser et al., 1990; Grimston et al., 1993; Matsumoto et al., 1997). In these studies, it was reported that it was more effective in judo and volleyball than in swimming in which one gravity load is limited, for increases in bone density in the spine and femur. However, the effect of sport particularly on the radius bone density in both arms was not examined or shown in previous studies. The present study did not show significant differences among the sports. This appears to be because the sports studied frequently have impact on the bone of both forearms.

In softball players and general students, a contralateral difference in radius bone densi- ty was not recognized. However, there were clear contralateral differences in badminton and soft-tennis players. The contralateral difference rate was $8.1 \%$ for soft-tennis players and $3.3 \%$ for badminton players, and in the soft-tennis players, one player showed an $18.8 \%$ contralateral difference rate. Few studies have reported the long-term effects of asymmetrical motion on bone density in athletes. Haapasalo et al. (1994) reported that there was $22.0 \%$ contralateral difference in the humerus in world class level female squash players. A simply comparison of the values in the present study with that of the world class level players may not be valuable. However, it was clearly confirmed that long-term continuation of a sport which showed dominant handedness also induced a clear contralateral difference in radius bone density in the humerus. These observations support the finding that increase in bone density occurs only in the loaded bone, not in the non-loaded bone (Colletti et al., 1989).

The development of the forearm in the dominant arm was also marked in badminton and soft-tennis players. That is to say, there was remarkable contralateral difference in forearm length, forearm girth (maximum and minimum) and grip strength. The forearm girth (maximum and minimum) and grip strength were mainly influenced by the muscle quantity. In this respect, Hyakutake et al. (1994) and Hughes et al. (1995) reported that the bone quantity and muscle quantity show a positive correlation. That is to say, the bone density has a close relationship with muscle force around the bone. The present study also confirmed the above point.

However, the contralateral difference in bone density in badminton players was 
smaller than that of the soft-tennis player. The reason for this difference is suggested as follows. Between the two sports, racket weight is different, and the degree of shock of a tennis ball and a shuttlecock against the racket is different. In addition, the soft-tennis players hit the ball using arms, while the badminton player hits the shuttlecock using a snap of the wrist as the main operation. Such factors may be producing the differences in the load for the radius between the two sports. The soft-tennis player who had the greater contralateral difference in grip strength showed the large side-to-side difference rate of bone density, while this phenomenon was not shown in badminton. In addition, there was a tendency of those with a higher difference to have a higher technology rank and sports experience years. This suggested that momentum and duration of sports experience influence the contralateral difference in radius bone density.

In addition, the non-dominant arm bone density of the badminton players was clearly higher than that of the general student. However, the soft-tennis player was almost equal to the general student. For this finding, there were contradictory reports. Vuori et al. (1994) reported that the bone density of the contralateral side increases even in unilateral leg press. In addition to muscle training effect, a cross-training effect may occur for bone density (Fukunaga, 1978). In contrast, Khan et al. (1996) reported that the increase in bone density was not generated in the non-loaded position in the arm of a ballet dancer. The present observations support these conflicting findings, respectively. The findings in soft-tennis players might be support the latter study, while the former can explain the findings in badminton players. However, it is not possible to clearly describe the differences of these issues. In future studies, motion analysis and detailed examination of the training content should be carried out to clarify the causes.

According to the above findings, the part of the skeleton which can expect an increase in bone density by the training motion is only the loaded bone. For athletes and regular sports participants who show dominant handedness, an imbalance between the right and left arms will occur in the radius bone density. Therefore, it is suggested that a training motion which loads the non-dominant arm must be intentionally adopted in training and daily life to maintain balance of the right and left radius bone densities.

\section{Reference}

Alfredson H, Nordstrom P, Lorentzon R (1996): Total and regional bone mass in female soccer players, Calcif Tissue Int, 59(6), 438-442

Alfredson H, Nordstrom P, Lorentzon R (1997): Bone mass in female volleyball players: a comparison of total and regional bone mass in female volleyball players and non-active females, Calcif Tissue Int, 60(4), 339-342

Colletti LA, Edwards J, Gordon L et al. (1989): The effects of muscle-building exercise on bone mineral density of the radius, spine, and hip in young men, Calcif. Tissue Int, 45(1), 1214

Fukunaga T (1978): Hitono zettaikinryoku, 182227, Kyorinsyoin, (Tokyo)

Grimston SK, Willows ND, Hanley DA (1993): Mechanical loading regime and its relationship to bone mineral density in children, Med Sci Sports Exerc, 25(11), 1203-1210

Haapasalo H, Kannus P, Sievanen H et al. (1994): Long-term unilateral and bone mineral density and content in female squash players, Calcif Tissue Int, 54(4), 249-255

Heinonen A, Oja P, Kannus P et al. (1995): Bone mineral density in female athletes represent- 
ing sports with different loading characteristics of the skeleton, Bone, 17(3), 197-203

Hughes VA, Frontera WR, Dallal GE et al. (1995): Muscle strength and body composition: associations with bone density in older subjects, Med Sci Sports Exerc, 27(7), 967-974

Hyakutake S, Goto S, Yamagata M et al. (1994): Relationship between bone mineral density of the proximal femur and lumbar spine and quadriceps and hamstrings torque in healthy Japanese subjects, Calcif Tissue Int, 55(3), 223229

Khan KM, Green RM, Saul A et al. (1996): Retired elite female ballet dancers and non-athletic controls have similar bone mineral density at weight-bearing sites, J Bone Miner Res, 11(10), 566-1274

Matsumoto T, Nakagawa S, Nishida S et al. (1997): Bone density and bone metabolic markers in active collegiate athletes: finding in longdistance runners, judoists and swimmers, Int $\mathrm{J}$ Sports Med, 18(6), 408-412
Natori R, Yokobori S, Ogawa Y, Kimura K (1975): Saishin tairyoku sokuteihou, 91-92, Doubunsyoin (Tokyo)

Risser WL, Lee EJ, Leblanc A (1990): Bone density in eumenorrheic female college athletes, Med Sci Sports Exerc, 22(5), 570-574

Simkin A, Ayalon J, Leichter I (1987): Increased trabecular bone density due to bone loading exercises in postmenopausal osteoporotic women, Calcif. Tissue Int, 40(2), 59-63

Stillman RJ, Lohman TG, Slaughter MH et al. (1986): Physical activity and bone mineral content in women aged 30 to 85 years, Med Sci Sports Exerc, 18(5), 576-580

Vuori I, Heinonen A, Sievanen H et al. (1994): Effects of unilateral strength training and detraining on bone mineral density and content in young women; a study of mechanical loading and deloading on human bones, Calcif Tissue Int, 55(1), 59-67

（受稿２000.6.5；受理２000. 9. 22） 